\title{
Taxonomic relationships in the genus Ammonia (Foraminifera) based on ribosomal DNA sequences
}

\author{
MARIA HOLZMANN ${ }^{1,2}$ and JAN PAWLOWSKI ${ }^{2}$ \\ ${ }^{1}$ Institut für Geologie und Paläontologie, Universität Graz, $8010 \mathrm{Graz}$, Austria \\ ${ }^{2}$ Département de Zoologie et Biologie animale, Université de Genève, 1224 Chêne-Bougeries, and Muséum d'Histoire naturelle, 1211 Genève 6 , \\ Switzerland.e-mail: holzmann@sc2a.unige.ch
}

\begin{abstract}
The genus Ammonia is a common benthic foraminifer which is widely distributed in nearshore marine environments. Its large morphological variability causes considerable difficulties in species identification. In the present study, we investigated taxonomic relationships in Ammonia by using a molecular approach based on ribosomal DNA sequences. We obtained 149 partial large subunit ribosomal DNA (LSU rDNA) sequences and 23 small subunit ribosomal DNA (SSU rDNA) sequences from 88 living Ammonia specimens which were collected from free-living populations in 14 localities. Sequence analysis revealed the presence of eight distinct genotypic groups (T1-T7, T9) and one distinct genotype that is represented by one specimen (T8). Examination of morphological characters shows that only one genotypic group can be clearly distinguished by its morphology. Biogeographical and ecological features are used for an additional characterization and it seems that the different groups live in relatively well defined environmental conditions and that only one genotypic group is cosmopolitan, while the others have a rather restricted geographical distribution. According to our study, three of the genotypic groups can be regarded as distinct species. J. Micropalaeontol. 19(1): 85-95, May 2000.
\end{abstract}

\section{INTRODUCTION}

Foraminifera are classified exclusively on the basis of the morphological characters of their tests. The value of these characters, however, is questionable for the determination of polymorphic taxa. Molecular techniques, especially the analysis of DNA sequences, provide a data set that is independent of morphological characters. This allows a revision of controversial taxonomic issues that cannot be solved with morphological data alone, as is the case for Ammonia.

The genus Ammonia, Brünnich, 1772, is widely distributed in nearshore and marginal marine environments. Extensive studies on its test structure and morphology have been published by Cifelli (1962), Banner \& Williams (1973) and Höttinger (1980). Vénec-Peyré (1980), investigated the chemical and mineralogical composition of extant and fossil Ammonia tests. The high morphologic variability of Ammonia leads to difficulties in the identification of species and has resulted in numerous discussions. Two conflicting theories prevail over the taxonomy of this genus. Some authors ('lumpers') consider that most Ammonia morphotypes are ecophenotypes of the same species while others ('splitters') claim that these morphotypes belong to different species (Schnitker, 1974; Poag, 1978; Wang \& Lutze, 1986; Walton \& Sloan, 1990; Haynes, 1992).

Recently, the analysis of partial ribosomal DNA sequences has been used to investigate inter- and intraspecific relationships in Ammonia (Pawlowski et al., 1995; Holzmann et al., 1996; Holzmann \& Pawlowski, 1997; Holzmann et al., 1998). Based on the analysis of LSU rDNA sequences, different genotypic groups could be distinguished for several morphotypes of Ammonia, thus evidently denying the hypothesis of one species represented by different ecophenotypes. Two genetically, morphologically and ecologically different types of Ammonia have been found in living foraminiferal assemblages from the Mediterranean Sea, North Atlantic and South Pacific, which were called Ammonia sp. 1 and Ammonia sp. 2 (Holzmann et al., 1996; Holzmann \& Pawlowski, 1997; Holzmann et al., 1998).

In the present study, we obtained partial rDNA sequences from 88 Ammonia specimens, collected in 14 different localities. The morphology of most specimens from which DNA was extracted was examined by scanning electron microscopy (SEM). Molecular data allowed us to distinguish eight different genotypic groups (T1-T7, T9) and one genotype comprising one sequence (T8). Among the genotypic groups, T1 and T2 correspond to the already previously described types of Ammonia sp. 1 and Ammonia sp. 2 respectively. Morphological, biogeographical and ecological data were used for an additional characterization of the different genetic groups.

\section{MATERIAL AND METHODS}

\section{Cell collection}

The specimens of Ammonia were sampled from different coastal regions of the Mediterranean Sea, Irish Sea, the English Channel, North Sea, North Atlantic, and Pacific (Fig. 1). Sediment samples from marginal marine environments were collected by hand with a scraper, as described by Holzmann et al. (1998). Ammonia specimens from rocky shores were collected from algae, attached to the rocks. Ammonia individuals from open marine habitats were collected by means of a grab sampler. The collected Ammonia specimens were maintained in laboratory cultures (Holzmann \& Pawlowski, 1996) and living individuals were isolated using a dissecting microscope.

\section{DNA extraction}

A total of 88 specimens, including those Ammonia individuals whose sequences are already published (Holzmann et al., 1996; Holzmann \& Pawlowski, 1997; Holzmann et al., 1998) have been used for this study. DNA was extracted one by one from all specimens. Every specimen was ground separately in extraction buffer, then incubated for 1 hour at $60^{\circ} \mathrm{C}$, followed by short centrifugation to remove the insoluble material (Holzmann \& Pawlowski, 1996). The morphology of 64 specimens was examined by SEM prior to DNA extraction. 


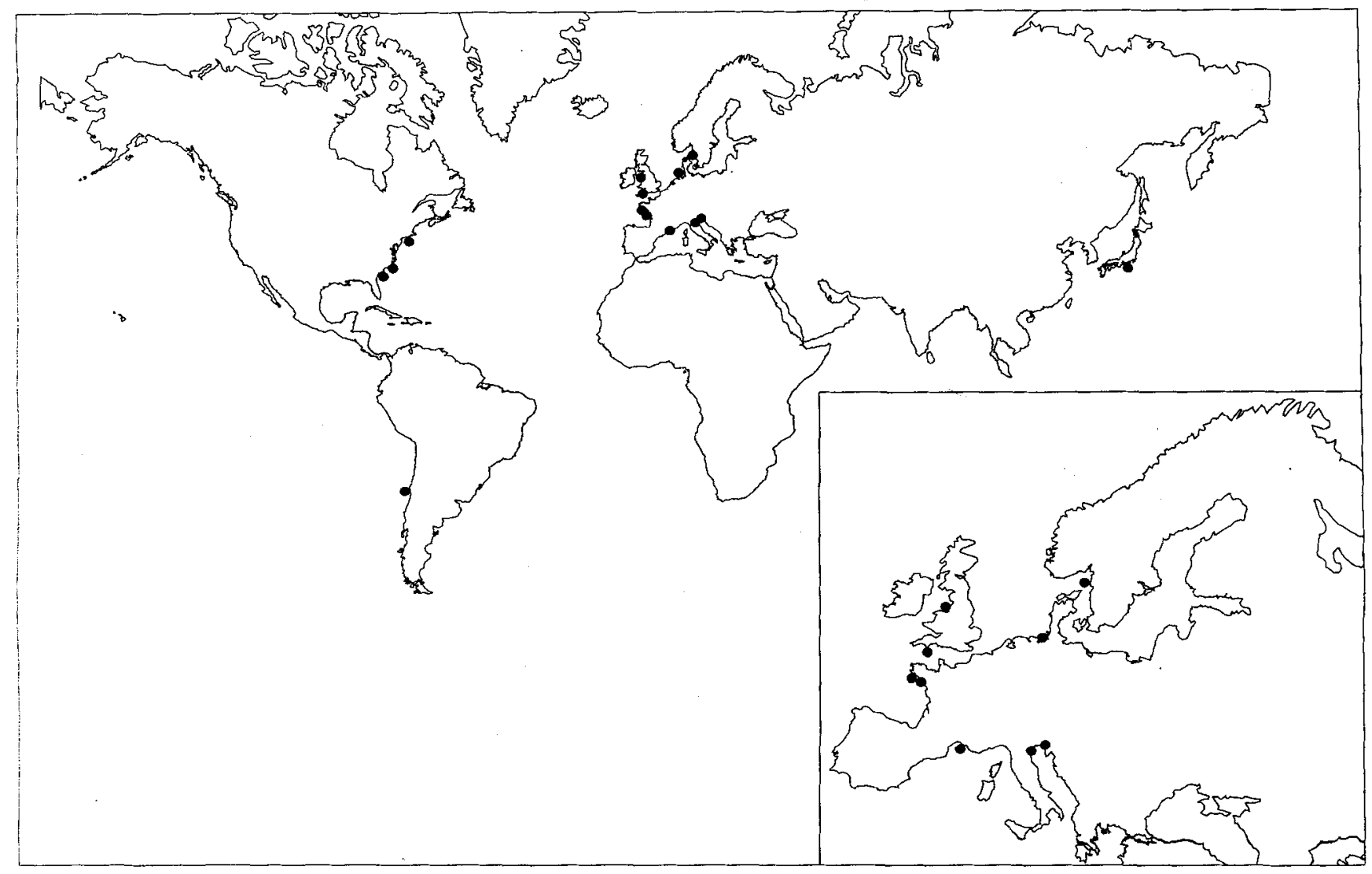

Fig. 1. Location map showing the collection sites.

PCR amplification, cloning and sequencing

A fragment of the LSU rDNA of about 650 nucleotides was amplified by PCR. Two specific foraminiferal LSU rDNA primers, Rib 2TA (5'CACATCAGCTCGAGTGAG; position 1-18 in rat) and Rib 1F (5'ACTCTCTCTTTCACTCC; position 385-402 in rat) were used for amplification (Holzmann \& Pawlowski, 1996). The amplified PCR products were purified using Spin-Bind DNA extraction Units (FMC) and cloned in the pGEM-T Vector system (Promega) using Supercompetent cells XL1-Blue MR (Stratagene). Both strands of a fragment of about 450 nucleotides were sequenced by using the specific foraminiferal primers Rib 2TA and Rib 7 (5'GATG(AT)GTCATTACCACC; position 309-324 in rat), (Holzmann \& Pawlowski, 1996). For 48 specimens, more than one clone was sequenced (between two and five clones per specimen).

Additionally, a fragment of the SSU rDNA of about 800 nucleotides was amplified for 23 specimens. Two specific foraminiferal SSU rDNA primers, s12 (5'CTACCAAAAGCGAAAGC; position 998-1002 in rat) and s14rf (5'CCTTCAAGTTTCACACTTGC; position 1183-1202 in rat) were used (Pawlowski et al., 1996). The PCR products were cloned and sequenced as described above, using the same primers for amplification and sequencing. One clone was sequenced per specimen.

\section{DNA sequence analysis}

Gel sequences were assembled using PC/Gene (Bairoch, 1989) and aligned manually, using the Genetic Data Environment (GDE), version 2.2 (Larsen et al., 1993). Evolutionary distances were computed according to Kimura's (1980) method of correction for multiple hits and unequal rates of transitions and transversions. All sites were retained for phylogenetic analysis, in order to maintain the minor intraindividual differences that occur in the sequences of some Ammonia specimens. Phylogenetic trees were built using the neighbor joining (NJ) (Saitou \& Nei, 1987) and maximum likelihood (ML) method (Olsen et al., 1994).

The reliability of internal branches in the NJ tree was assessed using the bootstrap method (Felsenstein, 1988) with 500 replicates for the NJ trees and 50 replicates for the ML trees. The phylo_win program (Galtier \& Gouy, 1996) was used for distance computations, inference of $N J$ and $M L$ trees and bootstrapping. The phylogenetic trees were plotted using the njplot program (Perrière \& Gouy, 1996).

The new sequences presented in this study were deposited in the EMBL/GenBank Nucleotide Sequence Database under accession numbers Z77773-Z77777, Z77779, Z77781, Z77783Z77787, Z77789, Z77791, Z77793, Z77795, Z77797, Z77799Z77825, X99811-X99824, AJ228517-AJ228548, AJ228552- 
AJ228559. Accession numbers for the LSU rDNA and SSU rDNA sequence of rat (Rattus norvegicus) used as references for primer positions are X01069 and K01593 respectively.

\section{RESULTS AND DISCUSSION}

\section{Sequence analysis}

\section{LSU rDNA fragment}

A fragment of the LSU rDNA was amplified and sequenced for 88 specimens. For 48 specimens, more than one clone was sequenced, resulting in a total of 149 LSU sequences (Table 1). The fragment is situated at the 5'terminal end of the LSU rRNA gene and includes the divergent domain $\mathrm{D} 1$ and flanking regions of the conserved domains $\mathrm{C} 1$ and $\mathrm{C} 2$ (Hassouna et al., 1984). Its length ranges from 364 to 421 nucleotides. The base composition of the analysed fragment is characterized by a relatively high proportion of $\mathrm{A}+\mathrm{T}$, which extends from $54 \%$ to $60.9 \%$. This is mostly due to serial repeats of $\mathrm{A}$ and $\mathrm{T}$ either as single nucleotides or as doublets.

Table 1. Number of investigated Ammonia specimens and of sequences obtained for the LSU and SSU rDNA fragments

\begin{tabular}{lccc}
\hline $\begin{array}{l}\text { Genetic } \\
\text { types }\end{array}$ & $\begin{array}{l}\text { Number of } \\
\text { specimens }\end{array}$ & $\begin{array}{c}\text { Number of } \\
\text { LSU sequences }\end{array}$ & $\begin{array}{c}\text { Number of } \\
\text { SSU sequences }\end{array}$ \\
\hline T1 & 26 & 44 & 7 \\
T2 & 36 & 57 & 6 \\
T3 & 9 & 16 & 3 \\
T4 & 3 & 6 & 1 \\
T5 & 2 & 4 & 1 \\
T6 & 3 & 6 & 1 \\
T7 & 6 & 12 & 2 \\
T8 & 1 & 1 & 1 \\
T9 & 2 & 3 & 1 \\
\hline
\end{tabular}

A phylogenetic tree, generated by the NJ method, reveals the presence of eight distinct genotypic groups of Ammonia (T1-T7, T9) and one genotype represented by one sequence (T8) (Fig. 2). All genotypic groups are monophyletic and supported by high bootstrap values $(97 \%-100 \%)$. Two monophyletic clades can be distinguished: One clade is composed of the genotypic groups $\mathrm{T} 2, \mathrm{~T} 3, \mathrm{~T} 4$ and $\mathrm{T} 5$ and supported by a bootstrap value of $94 \%$. Another clade is formed by the genotypic groups T6 and T7, but its monophyly is supported by a much lower bootstrap value $(61 \%)$. The genotype T8 branches between these two monophyletic clades, but its separation from the clade containing T6 and $\mathrm{T} 7$ is supported by a very low bootstrap value $(33 \%)$. T1 and $\mathrm{T} 9$ branch separately, with $\mathrm{T} 1$ as a sister group to $\mathrm{T} 2-\mathrm{T} 8$ and T9 as a sister group to all other genotypic groups.

Pairwise comparison of the sequences shows a high sequence dissimilarity between and within the investigated genotypic groups (Table 2). Sequence divergence between genotypic groups ranges from $5.5 \%$ to $28.6 \%$. and reaches up to $11.6 \%$ within a single genotypic group (T1). The comparison of different clones, obtained from the same individual shows that the examined fragment of the rDNA is polymorphic (Holzmann et al., 1996). The intra-individual variation was found in each group, with the lowest values in T3 $(\leq 0.7 \%)$ and the highest values in $\mathrm{T} 1(\leq 7.7 \%)$.

\section{SSU rDNA fragment}

A fragment of the SSU rDNA was obtained for each genotypic group and the genotype, by investigating one representative from each sampling locality (Table 1). The amplified fragment is located in the middle part of the SSU rDNA gene and its length varies from 481 to 573 nucleotides. It includes the variable area V5 and flanking helices 24 and 25 as well as parts of the flanking helices 21, 22, 26 and 28 (Neefs \& Wachter, 1990). The A + T content ranges from $54.3 \%$ to $57.9 \%$.

Phylogenetic trees were inferred by NJ and ML methods. The NJ tree of the SSU rDNA sequences (Fig. 3) is nearly identical to the LSU rDNA tree and differs only in two points from the latter one. First, the genotype T8, which branches separately in the LSU rDNA tree, forms a a well supported $(100 \%)$ clade with the genotypic group T6. The second difference concerns the branching order in the clade comprising the genotypic groups $\mathrm{T} 2, \mathrm{~T} 3, \mathrm{~T} 4$ and T5. While T3 branches as a sister group to the others in the LSU rDNA tree, T4 and T5 form a sister group to the others in the SSU rDNA tree.

ML analysis of the SSU rDNA fragment results in a tree that is very similar to the NJ tree in Figure 3 (data not shown). Two monophyletic clades were observed, one consisting of the genotypic groups T2, T3, T4 and T5 and the other comprising the genotypic groups $\mathrm{T} 1, \mathrm{~T} 6$ and $\mathrm{T} 7$. The main difference between the ML and the NJ SSU rDNA trees consists in the position of $\mathrm{T} 1$ which does not form a sister group to all others in the ML tree.

Table 2. Relative frequence of differences in partial LSU rDNA sequences of Ammonia spp.

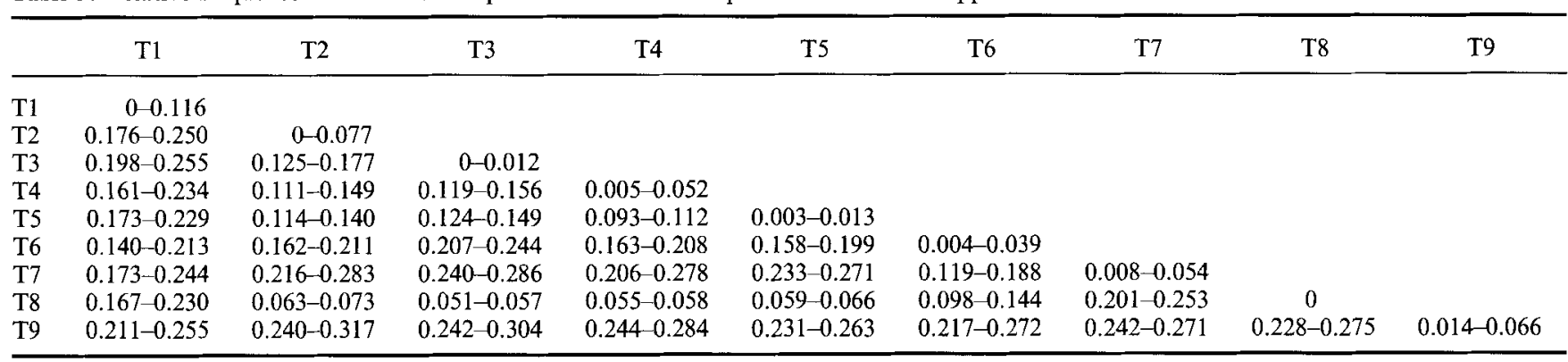




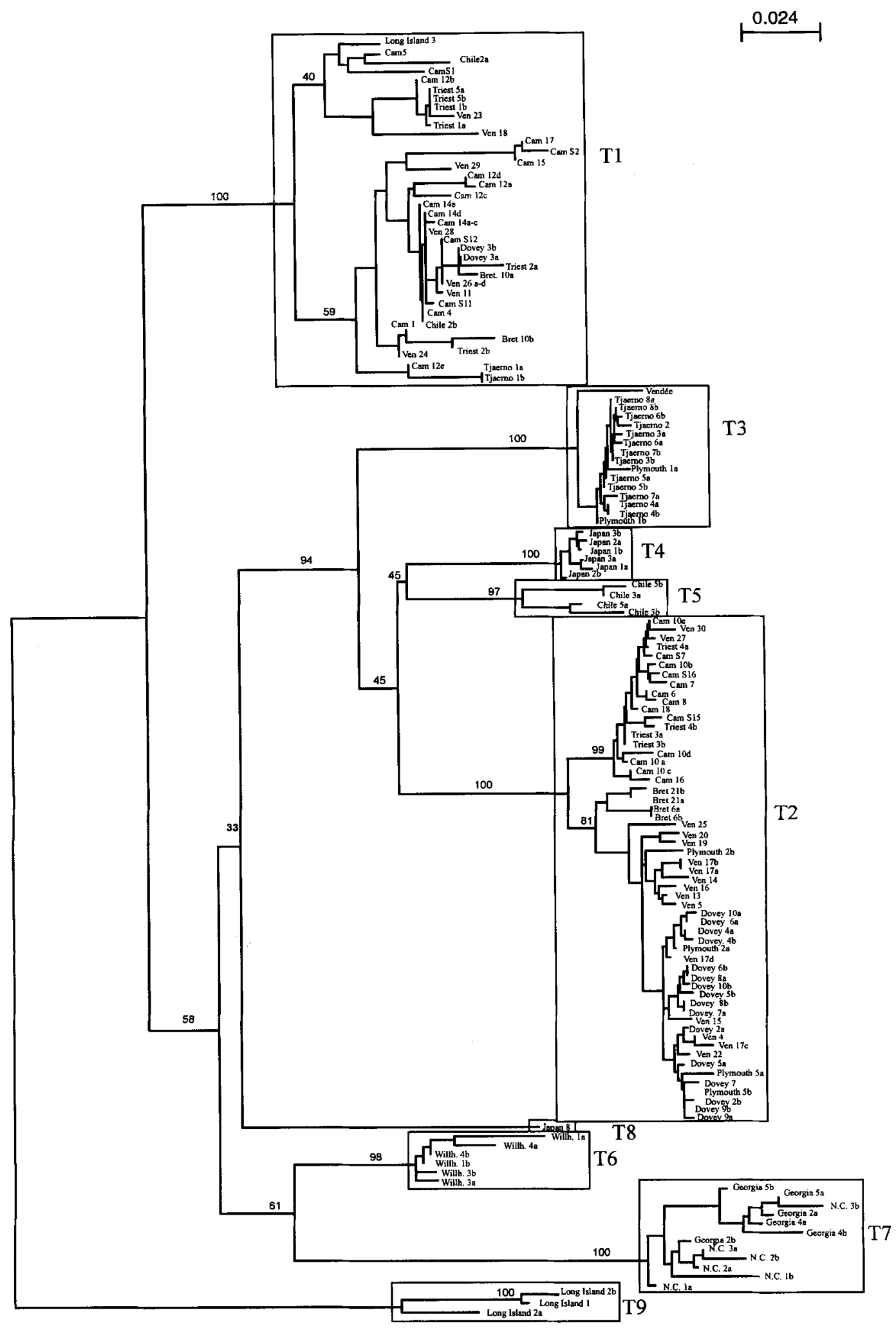

Fig. 2. Phylogenetic analysis of 144 partial LSU rDNA sequences using the NJ method. The numbers are bootstrap percent values based on 500 replicates. The sequences of different clones originated from the same specimen are indicated by letters a-e.

List of used abbreviations: Bret, Bretagne; Cam, Camargue; N.C, North Carolina; Wilh., Wilhelmshaven; Ven, Venice. 


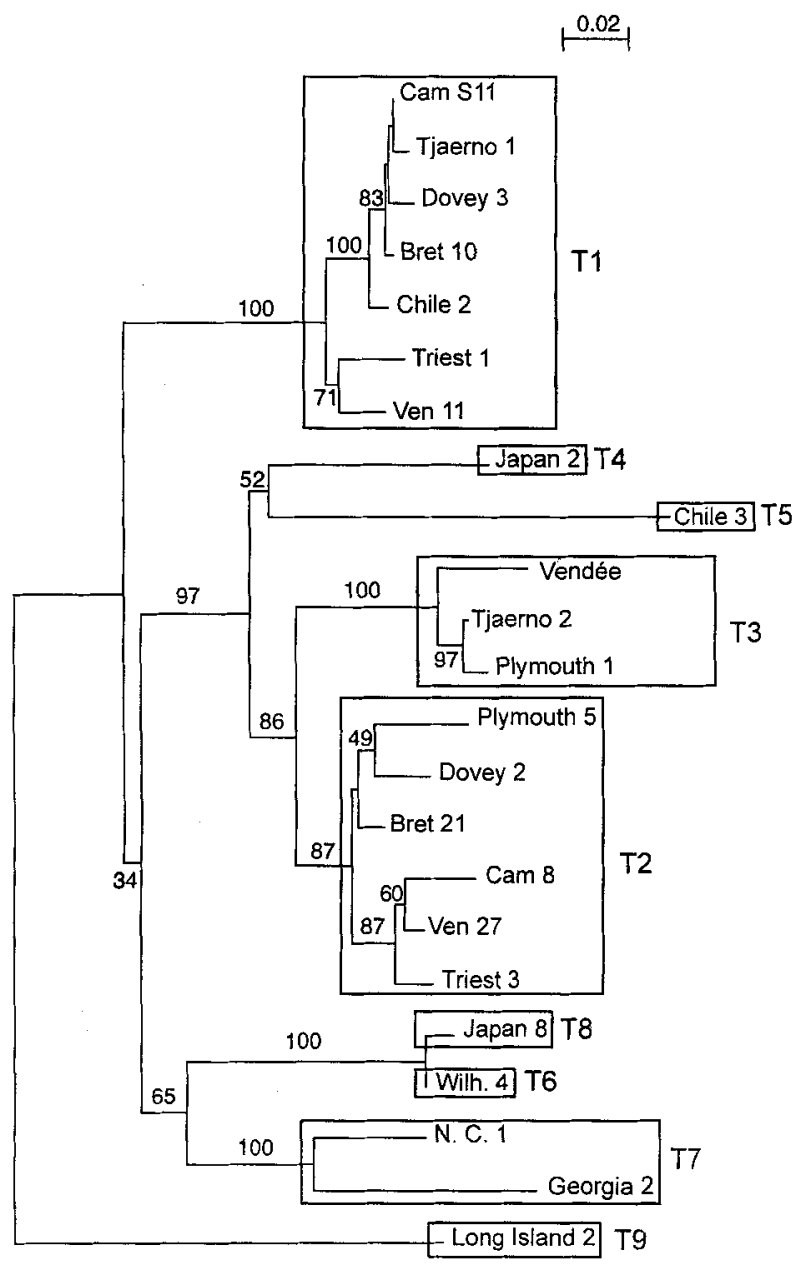

Fig. 3. Phylogenetic analysis of 23 partial SSU rDNA sequences using the NJ method. The numbers indicate bootstrap percent values based on 500 replicates.

\section{Combined analysis of the LSU and SSU rDNA fragment}

The corresponding sequences of the LSU rDNA were joined to the SSU rDNA data set and analysed as one fragment. The NJ tree (not shown) shows nearly the same branching pattern as the tree in Figure 2. The only difference to the latter concerns the position of $\mathrm{T} 8$, which forms a cluster with $\mathrm{T} 6$, as in the $\mathrm{NJ}$ tree of the SSU rDNA fragment. ML analysis of the combined fragments results in a tree (not shown) that is identical to the tree in Figure 3.

\section{MORPHOLOGY}

Typical specimens representing each genotypic group and the single genotype of Ammonia are illustrated on Plates 1 and 2. Among the eight genotypic groups and the one genotype differentiated by DNA sequence analysis, only T3 (Plate 1, fig. 1a-b) can be clearly distinguished by its morphology. It is the largest among all Ammonia examined in this study. Its test has a mean diameter of $0.62 \mathrm{~mm}$, while the diameter of other Ammonia types does not exceed $0.4 \mathrm{~mm}$. It is characterized by a thick walled, low trochospiral test. The spiral sutures are distinct and deeply incised in the last whorl. The sutural areas on the umbonal side are stud with numerous irregular knobs. The beading, fluting and/or furrowing along the umbonal sutures is typical for these strongly ornamented forms. The umbonal cavity is filled up with numerous calcareous plugs of different size.

In other groups, some distinct features have been observed. For example, Holzmann \& Pawlowski (1997) and Holzmann et al. (1998) have shown that Tl specimens are characterized by very distinct spiral sutures and that they can be distinguished from $\mathrm{T} 2$ specimens by their test size and pore diameter. The genotypic groups T4, T5 and T6, however are quite similar to T2 in their external appearance and although they are genetically clearly distinct, a separation on the basis of morphological features is not possible.

Specimens belonging to $\mathrm{T} 7$ also display some morphological differences: their chambers are rather elongated and not rounded like in other Ammonia and the last chamber is considerably inflated in most individuals. The genotypic group T9 differs from other investigated Ammonia in having a large umbilical plug and that the umbilical space between the plug and the chamber flaps is completely closed by smooth, calcareous fillings. The single Ammonia specimen representing T8 is characterized by extremely fine, elongated and pointed chamber flaps.

With the exception of the genotypic groups T1-T3, only a few specimens could be investigated for each other group (T4 - T7 and T9) and one specimen could be examined for T8. It is therefore not possible to draw any conclusions about the general morphology for most types of Ammonia. A closer investigation on a population level will be necessary to see if the genetically distinct types of Ammonia can also be distinguished morphologically from each other.

\section{BIOGEOGRAPHY AND ECOLOGY}

An overview of the habitats and geographic distribution of each genotypic group is given in Table 3. The majority of samples were collected from microtidal salt marshes. Few samples were also taken from meso- to macrotidal flats, a brackish water lake, rocky shores and open marine habitats. Although the number of sampling localities is limited, it seems that at least some of these groups have a rather restricted geographical distribution and live in relatively well defined environmental conditions.

Only one genotypic group, $\mathrm{T} 1$ seems to be cosmopolitan. It is present in all samples from microtidal marshes in Europe, on the northeast coast of the United States and in Chile. It was not found however, in samples from similar habitats on the southeast coast of the USA and in Japan. In European salt marshes, the genotypic groups $\mathrm{T} 1$ and $\mathrm{T} 2$ commonly occur together. T1 was also found in Long Island (N.Y.) and La Ligua (Chile), where it occurs together with other genotypic groups, respectively T9 and T5. Although T1 usually seems to share its habitat with a second genotypic group of Ammonia, both may not have the same ecological preferences. A former study, based on specimens sampled from the Lagoon of Venice shows some ecological differences in the distribution of $\mathrm{T} 1$ and $\mathrm{T} 2$ (Holzmann \& Pawlowski, 1997). T1 is mainly confined to the internal, silty part of the Lagoon which is rich in nutrients, whereas $\mathrm{T} 2$ is dominant in the outer, sandy part of the Lagoon 


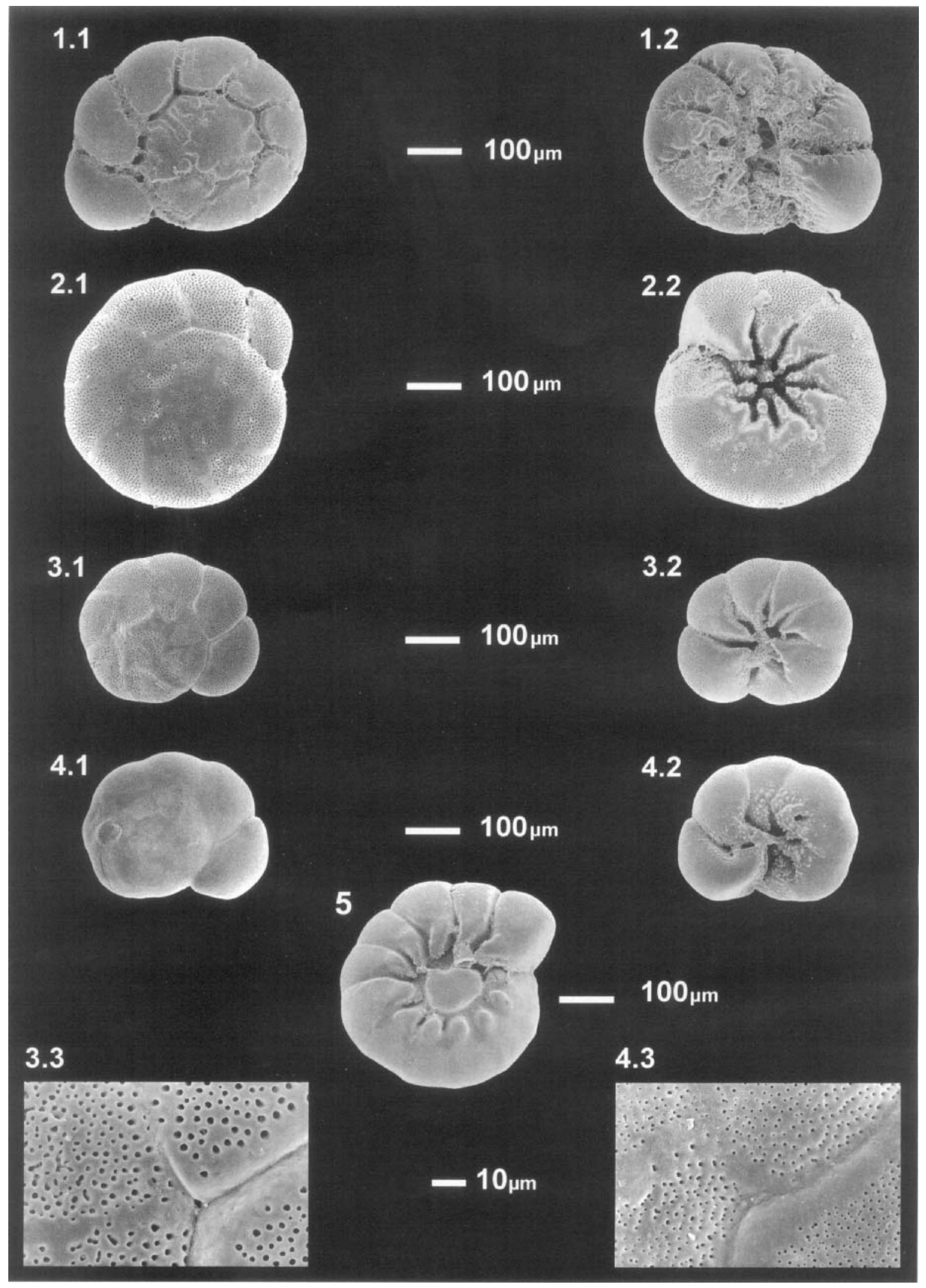

Explanation of Plate 1.

figs 1.1-4.1: spiral view, figs 1.2-4.2, 5: umbilical view; figs 3.3-4.3: enlargement of an area between the last and the penultimate chamber and the spiral sutures in the last whorl; magnifications: $\times 1400$; figs 1.1, 1.2: Ammonia specimen/T3 (Tjaerno); figs 2.1, 2.2: Ammonia specimen/T8 (Hamana Lake); figs 3.1, 3.2, 3.3: Ammonia specimen/T1 (Dovey Estuary); figs 4.1, 4.2, 4.3: Ammonia specimen/T2 (Dovey Estuary); fig 5: Ammonia specimen/ T9 (Long Island). 
6.1
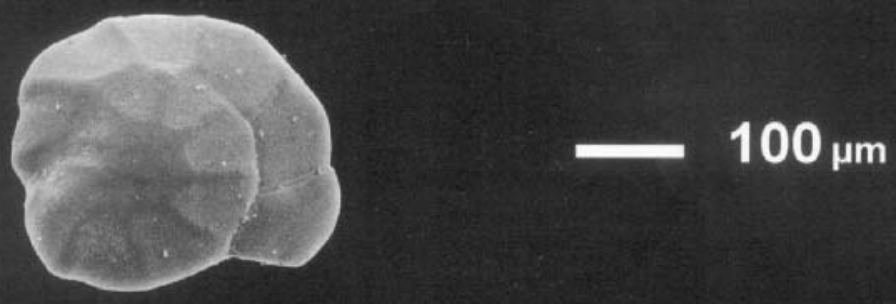

6.2
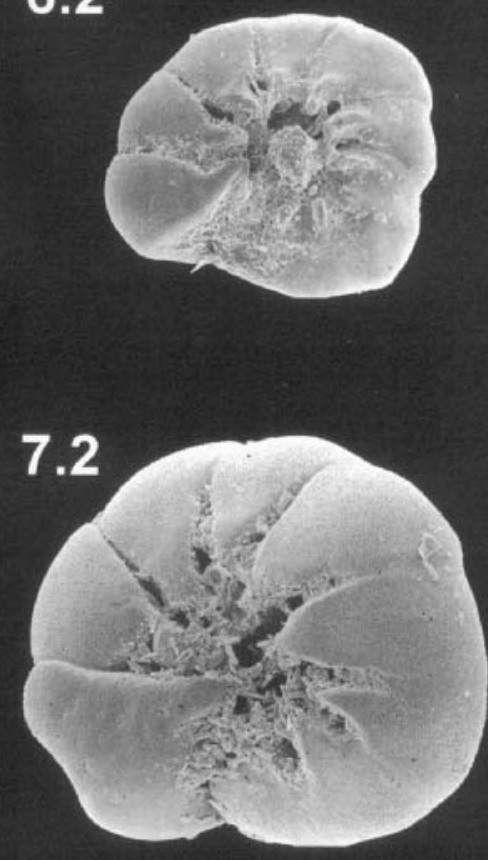

8.2

8.1

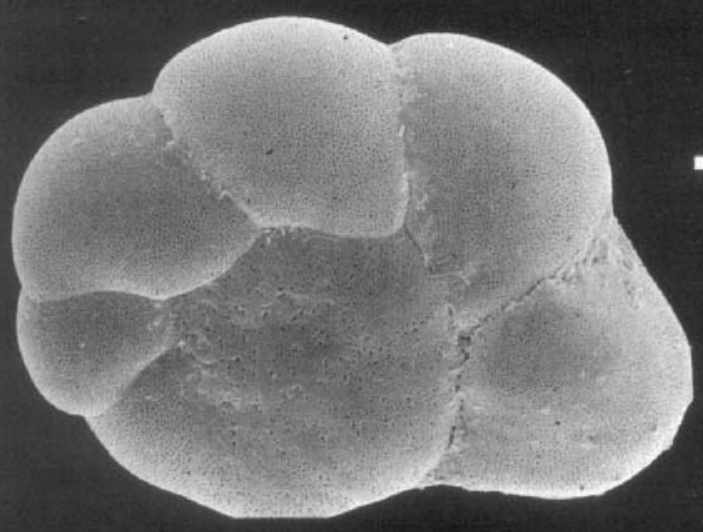

$100 \mu \mathrm{m}$
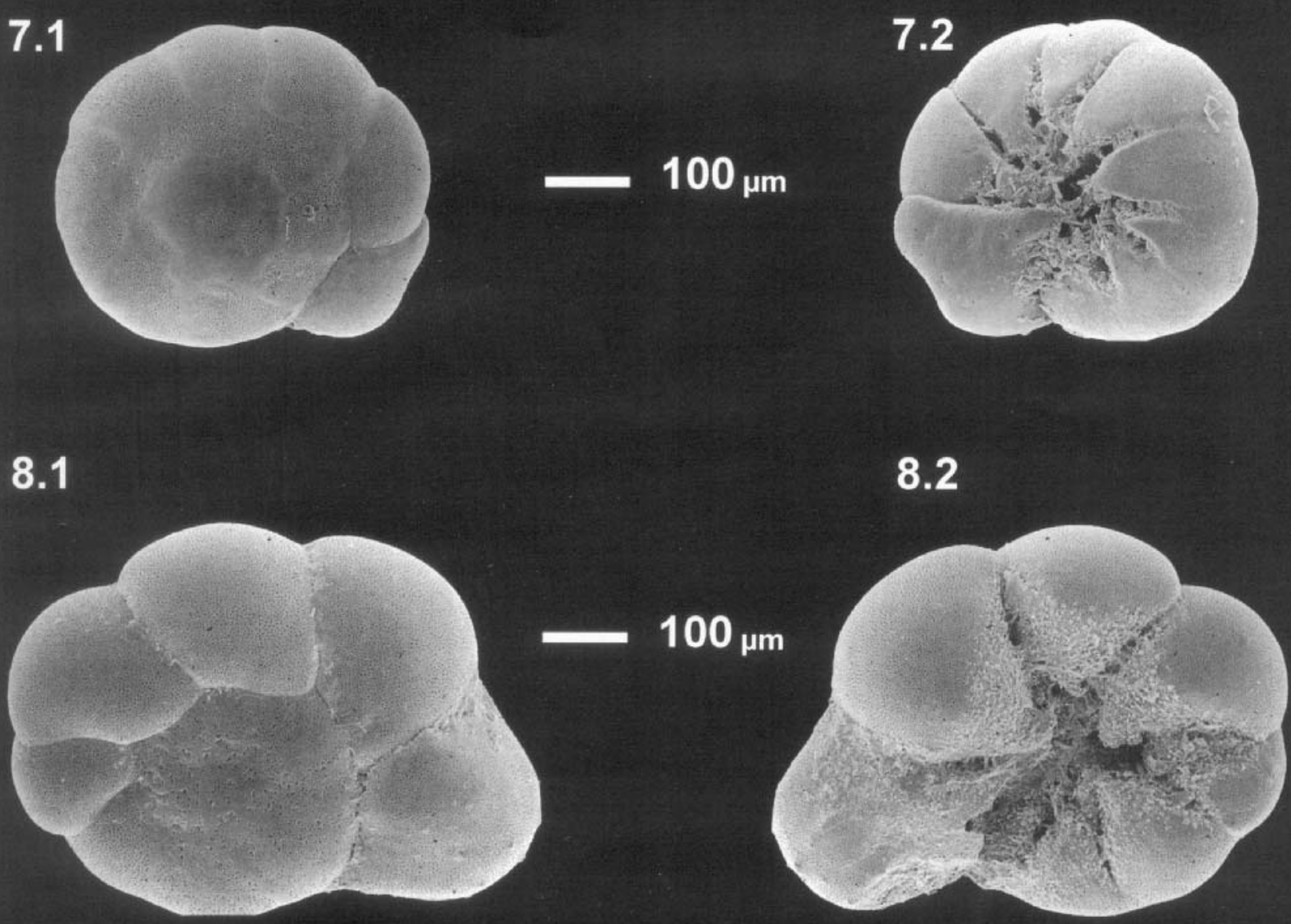

9.2

$100 \mu \mathrm{m}$

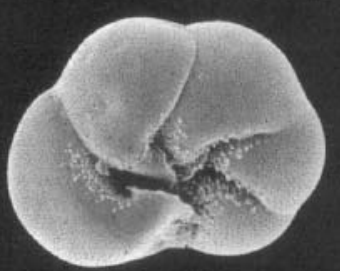

Explanation of Plate 2.

figs 6.1-9.1: spiral view, figs 6.2-9.2: umbilical view; figs 6.1, 6.2: Ammonia specimen/T4 (Hamana Lake); figs 7.1, 7.2: Ammonia specimen/T5 (La Ligua); figs 8.1, 8.2: Ammonia specimen/T6 (Wilhelmshaven); figs 9.1, 9.2: Ammonia specimen/T7 (Georgia). 
Table 3. Distribution and habitat of investigated Ammonia specimens

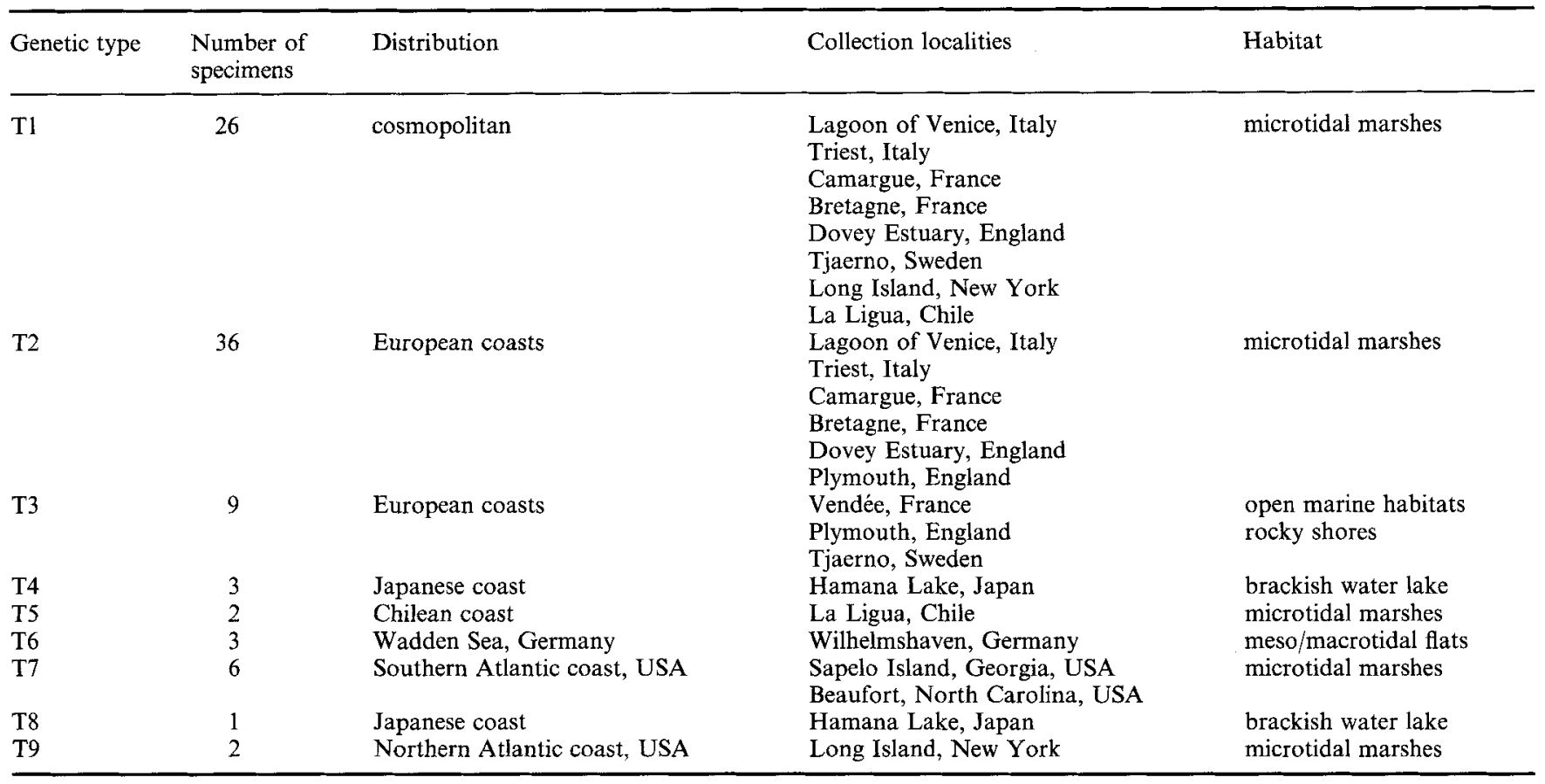

which contains less organic detritus, but has higher oxygen levels than the inner part.

With the exception of $\mathrm{T} 1$, all other marsh-inhabiting Ammonia have a relatively restricted geographic distribution. A distinct genotypic group $\mathrm{T} 5$ was found in salt marshes from Chile. Two other genetically different types (T4, T8) have been sampled from the brackish water Hamana Lake, in Japan. One genotypic group (T4) might represent a local form, while the other type (T8) shows some genetic affinities to T6.

Another genotypic group, T6, was identified in the Wadden Sea, which is part of the Southern North Sea. The Wadden Sea is the largest continous tide dominated depositional environment in the world (Reineck, 1978; Janke \& Kraemer, 1990). It is a meso- to macrotidal environment and the sediment surface is widely covered with a diatom carpet. Living Ammonia specimens can be easily gained from the surface sediment layers. More samples from different stations of the the North Sea will be needed to clarify the question if T6 specimens are unique to the Wadden Sea or if they also occur in other parts of the North Sea.

The genotypic group $\mathrm{T} 7$ seems to be characteristic for southern salt marshes in the USA. Ammonia specimens of T7 occur south of Cape Hatteras, along the Atlantic coast of the USA. Warm Gulf stream water characterizes this coastal region and the foraminiferal assemblages are generally dominated by warm water species (Schnitker, 1971). T7 specimens differ genetically and morphologically from Ammonia spp. sampled in Long Island (T1 and T9). In the latter case, the coastal water is influenced by the cold Labrador Current Extension, the different Ammonia types might thus be adapted to different climatic regions.

The genotypic group T3 represents the only Ammonia group that inhabits rocky shores and open marine habitats. T3 representatives were only collected from European coasts. Given the limited number of samples, however, the distribution of this group might not be restricted to this area. According to Jorissen (1988) who investigated Ammonia specimens that correspond morphologically to $\mathrm{T} 3$, this form seems to be not so much dependent from a special substrate type, but has a rather specialized food uptake, which includes epi-benthic deposit feeders in areas without vegetation as well as forms that collect food from the vegetation cover.

\section{TAXONOMIC REMARKS}

The substantial question is whether the different genotypic groups of Ammonia can be considered as distinct species or not. It has been shown for planktonic foraminifera, that morphospecies can include different genotypes which are in some cases highly divergent and represent examples of cryptic speciation (Huber et al., 1997; Darling et al., 1999; De Vargas et al., 1999). The investigated Ammonia specimens cluster in different, well defined genotypic groups and by comparing the genetic distances between these groups to the level of divergence in cryptic species of planktonic foraminifera, the former could be regarded as distinct species of Ammonia. Most of the genotypic groups of Ammonia, however contain only a few individuals from one sampling site (T4-T7, T9). Because of the limited sample size these genotypic groups cannot be regarded with certainty as distinct species and further investigations on a population level have still to be carried for each of these groups as well as for the genotype T8. For three of the genotypic groups (T1-T3), however there are some arguments in favor for their taxonomic status as distinct species.

$\mathrm{T} 1$ and $\mathrm{T} 2$ have been investigated on a population level. They 
are genetically clearly distinguished and may be adapted to different ecological conditions (Holzmann \& Pawlowski, 1997; Holzmann et al., 1998). $\mathrm{T} 1$ and $\mathrm{T} 2$ show a partly overlapping biogeographical distribution and, where they occur in sympatry in the same habitat, they seem to be reproductively isolated, as no hybrids have been identified until now. Specimens belonging to the genotypic group $\mathrm{T} 3$ are characterized by very distinct morphological features, are genetically well defined and occur in different habitats, compared to the other Ammonia types.

The problem that remains to be solved, however, is whether existing specific names can be used to describe the different genotypic groups of Ammonia or not. Given the 'nomenclatural chaos' that reigns over the taxonomy of Ammonia, this is not an easy task. Table 4 presents a list of some taxonomic identifications that match different genetic types of Ammonia. Among the eight groups, there are only two (T3, T9) whose taxonomic identification is relatively easy.

Table 4. Some taxonomic identifications for different Ammonia types

\begin{tabular}{|c|c|c|}
\hline $\begin{array}{l}\text { Genetic } \\
\text { type }\end{array}$ & $\begin{array}{ll}\text { ic } & \text { Taxonomic } \\
\text { identification }\end{array}$ & References \\
\hline \multirow[t]{4}{*}{$\mathrm{T} 1$} & A. tepida & $\begin{array}{l}\text { Daniels (1970) } \\
\text { Zaninetti (1984) } \\
\text { Cimerman \& Langer (1991) } \\
\text { Hohenegger et al. }(1993)\end{array}$ \\
\hline & A. beccarii forma rigonfa* & Albani \& Serandrei-Barbero (1990) \\
\hline & Rotalia veneta & Schultze (1854) \\
\hline & Rotalia inca & Cushman \& Kellett (1929) \\
\hline \multirow[t]{2}{*}{$\mathrm{T} 2$} & A. aberdoveyensis & Haynes (1973) \\
\hline & $\begin{array}{l}\text { A. parkinsoniana forma } \\
\text { parkinsoniana }\end{array}$ & Jorissen (1988) \\
\hline $\mathrm{T} 3$ & A. beccarii & $\begin{array}{l}\text { Jorissen (1988) } \\
\text { Debenay et al. (1998) }\end{array}$ \\
\hline $\mathrm{T} 4$ & A. beccarii forma 2 & Matoba $(1970)$ \\
\hline T5 & Rotalia inca & Boltovskoy (1976) \\
\hline \multirow[t]{3}{*}{ T6 } & $\begin{array}{l}\text { Rotalia beccarii var. } \\
\text { flevensis }\end{array}$ & Hofker (1930) \\
\hline & Streblus beccarii tepida & Richter (1967) \\
\hline & Ammonia beccaril var. & Phleger (1970) \\
\hline \multirow[t]{3}{*}{$\mathrm{T} 7$} & A. beccarii & Akers (1970) \\
\hline & A. beccarii forma tepida & Goldstein \& Moodley (1993) \\
\hline & A. parkinsoniana & Goldstein \& Frey (1986) \\
\hline T8 & A. beccarii forma 1 & Matoba (1970) \\
\hline \multirow[t]{2}{*}{ T9 } & A. parkinsoniana & $\begin{array}{l}\text { Cushman \& Cole (1930) } \\
\text { Pawlowski et al. (1995) }\end{array}$ \\
\hline & $\begin{array}{l}\text { Rotalia beccarii var. } \\
\text { sobrina }\end{array}$ & Shupack (1934) \\
\hline
\end{tabular}

The description of these species also fits $T 2$ specimens

The genotypic group T3 can be most probably assigned to Ammonia beccarii, to which it corresponds in its external morphological features. $A$. beccarii was first described as Nautilus beccarii by Linné (1758), but a type specimen does not exist. Later investigations on material from the type locality (Rimini, Adriatic Sea, Italy) have been carried out by d'Orbigny (1826), Cushman (1928) and Cifelli (1962). All A. beccarii so far described from the type locality resemble in its external features the genotype T3.

The T3 specimens used in our study however, were sampled from the Western Atlantic, North Sea and the English Channel. Hofker (1951) described strongly ornamented Ammonia individuals from the North Sea as Streblus batavus and considered these forms being different from Adriatic $A$. beccarii, although he states that the two forms 'suggest much resemblance' (Hofker, 1951, p. 501). According to his description, A, batavus is characterized by having secondary chambers while he could never observe such a feature in Adriatic $A$. beccarii. Vénec-Peyré (1983) however, described $A$. beccarii from the French Mediterranean coast and reported variation along a morphological cline between 'batavus' forms, having interlocular spaces that correspond to Hofker's secondary chambers and 'beccarii' forms, lacking them. Considering the existence of these transitional stages, $A$. batavus might be a junior synonym of $A$. beccarii, but to date we do not have any sequences of $A$. beccarii specimens from the Adriatic Sea that could be used for a molecular comparison with $\mathrm{T} 3$ specimens.

T9 specimens resemble in their morphology Ammonia parkinsoniana. The species was first described by d'Orbigny (1839a) from recent sediments of Cuba, but a type specimen does not exist. A neotype was determined by Le Calvez (1977) and deposited in the collections of the Museum d'Histoire Naturelle in Paris, but it got lost (pers. comm., Dr MarieThérèse Vénec-Peyré). Therefore our determination is based solely on a comparison of our specimens with illustrations of the neotype presented by Le Calvez (1977, pl. 11, fig. 1-3). Ammonia specimens which are akin to the illustrated neotype of $A$. parkinsoniana and which were sampled from the same locality (Long Island) as our T9 specimens have been described as Rotalia beccarii var. sobrina by Shupack (1934). The specimens illustrated by Shupack (1934) (fig. 4a-c) also correspond in their external morphology to our $\mathrm{T} 9$ specimens and considering the morphological resemblance of the latter with the neotype of $A$. parkinsoniana, Rotalia beccarii var. sobrina might be a junior synonym of $A$. parkinsoniana.

It is much more difficult to attribute specific names to the remaining genotypic groups. Most of the Ammonia morphotypes found in our samples are usually described as $A$. beccari or $A$. tepida. The latter name is often used for morphotypes similar to T1 (Zaninetti, 1984; Cimerman \& Langer, 1991; Debenay et al., 1998). However, in a previous study (Holzmann \& Pawlowski, 1997), we examined the test morphology of 14 syntypes of $A$. tepida from the Cushman collection of the Smithsonian Institution, Washington D.C. (courtesy of Dr Martin Buzas) and found their test morphology different, compared to T1 specimens. But as no living specimens of $A$. tepida from the type locality (San Juan Harbour, Puerto Rico) have been genetically analysed so far, a molecular comparison between $A$. tepida and T1 specimens is not possible.

One possible solution to resolve the problem of taxonomic determination would be the use of names that have been given to some local populations of Ammonia. For example, the genotypic group $\mathrm{T} 2$ could be most probably assigned to Ammonia aberdoveyensis (Haynes, 1973). This species is characterized by a low conical test with rounded periphery and a lack of ventral ornament, test diameter averaging $0.40 \mathrm{~mm}$, which is comparable to mean test size of $T 2$. By sequencing nine living specimens from the type locality (Dovey Estuary, England), it turned out that eight of them are indeed branching within T2. However, 
one specimen of the type locality clusters among $\mathrm{T} 1$ specimens. The Ammonia assemblage from the type locality consists thus of two different genotypic groups. But as $\mathrm{T} 1$ specimens do not correspond in their external features to the type description of $A$. aberdoveyensis, the name could be used for $\mathrm{T} 2$.

If such names are used, however, their validity has to be verified. For example, the Ammonia specimens from Chile have been assigned to Rotalia inca by Cushman \& Kellett (1929) and have been considered as an endemic South American species (Boltovskoy, 1976). The species was first described by d'Orbigny (1839b) as Rosalina inca from Lima, Peru, and its type specimen is preserved in the Museum d'Histoire Naturelle in Paris. We have examined the type specimen specimen and found out that it is definitely not an Ammonia.

Given the complexity of the problem of taxonomic determination of Ammonia, we prefer to use an open nomenclature (Holzmann \& Pawlowski, 1997; Holzmann et al., 1998). In this way we avoid the creation of the new specific names, which would only further contribute to the confusing taxonomy of Ammonia.

\section{Acknowledgements}

Special thanks are extended to W. Piller and L. Zaninetti. We would further like to express our gratefulness towards all people that contributed to our work either by sending us samples or by helping us collecting, especially J. Bernhard, J. P. Debenay, S. Goldstein, J. Haynes, H. Kitazato, C. Manley and J. MontoyaBurgos. We would also like to thank J. Fahrni for technical assistance. Previously unpublished aspects of work reported here were funded by grants from the Austrian 'Fonds zur Foerderung der wissenschaftlichen Forschung', projects PO9817-BIO and P12105-BIO (M. H.) and by the Swiss Natural Science Foundation grant 3100-49513.96 (J. P.).

\section{Manuscript received 25 February 1999 Manuscript accepted 5 December 1999}

\section{REFERENCES}

Albani, A. and Serandrei - Barbero, R. 1990. I Foraminifera della Laguna e del Golfo di Venezia. Memorie Di Scienze Geologiche dell' Università di Padova, 62: 271-341.

Akers, W. H. 1971. Estuarine foraminiferal associations of the Beaufort area, North Carolina. Tulane Studies in Geology and Paleontology, 8: 147-165.

Bairoch A. 1989. PC/Gene, IntelliGenetics, Inc.; Geneva.

Banner, F. T. \& Williams, E. 1973. Test structure, organic skeleton and extrashell cytoplasm of Ammonia Brünnich. Journal of Foraminiferal Research, 3: 49-69.

Boltovskoy, E. 1976. Distribution of recent foraminifera of the South American region, In Hedley, R. H. \& Adams, C. G. (Eds), Foraminifera, v. 2. Academic Press, London: 171-236.

Cifelli, R. 1962. The morphology and structure of Ammonia beccarii (Linné). Contributions from the Cushman Foundation for Foraminiferal Research, 13: 119-126.

Cimerman, F. \& Langer, M. 1991. Mediterranean Foraminifera: Academia Scientiarum et Artium Slovenica, Classis IV: Historia Naturalis, Ljubljana, 76-77.

Cushman, J. A. 1928. On Rotalia beccarii (Linné). Contributions from the Cushman Laboratory for Foraminiferal Research, 4: 103-107.

Cushman, J. A. \& Cole, W. S. 1930. Pleistocene foraminifera from Maryland. Contributions from the Cushman Laboratory for Foraminiferal Research, 6: 94-100.

Cushman, J. A. \& Kellett, 1929. Recent foraminifera from the West coast of South America. Proceedings of the U. S. National Museum, 75: $1-16$.

Daniels, C. H. 1970. Quantitative oekologische Analyse der zeitlichen und raeumlichen Verteilung rezenter Foraminiferen im Limski Kanal bei Rovinj (Noerdliche Adria). Goettinger Arbeit zur Geologie und Palaeontologie, 8: 1-109.

Darling, F. K., Wade, M. C., Kroon, D. \& Leigh Brown, J. A. 1999. The diversity and distribution of modern planktic foraminiferal small subunit ribosomal RNA genotypes and their potential as tracers of present and past ocean circulations. Paleoceanography, 14: 3-12.

Debenay, J. P., Bénéteau, E., Zhang, J., Stouff, V., Geslin, E., Redois, F. \& Fernandez-Gonzalez, M. 1998. Ammonia beccarii and Ammonia tepida (Foraminifera): morphofunctional arguments for their distinction. Marine Micropaleontology, 34: 235-244.

De Vargas, C., Norris, R., Zaninetti, L., Gibb, W. S. \& Pawlowski, J. 1999. Molecular evidence of cryptic speciation in planktonic foraminifers and their relation to oceanic provinces. Proceedings of the Natural Academy of Sciences, USA, 96: 2864-2868.

Felsenstein, J. 1988. Phylogenies from molecular sequences: inference and reliability. Annual Review of Genetics, 22: 521-565.

Galtier, N. \& Gouy, M. 1996. SEAVIEW and PHYLO_WIN: two graphic tools for sequence alignment and molecular phylogeny. Computer Applications in Bioscience, 12: 543-548..

Goldstein, S. T. \& Frey, R. W. 1986. Salt Marsh Foraminifera, Sapelo Island, Georgia. Senckenbergiana Maritima, 18: 97-121.

Goldstein, S. T. \& Moodley, L. 1993. Gametogenesis and the life cycle of the foraminifera Ammonia beccarii (Linné) forma tepida (Cushman). Journal of Foraminiferal Research, 23: 213-220.

Hassouna, N., Michot, B. \& Bachellerie, J. P. 1984. The complete nucleotide sequence of mouse $28 \mathrm{~S}$ rRNA gene. Implications for the process of size increase of the large subunit rRNA in higher eukaryotes. Nucleic Acids Reserach, 12: 3563-3583.

Haynes, J. R. 1973. Cardigan bay recent foraminifera. Bulletin of the Brithish Museum (Natural History) Zoology, supplement, 4: 184-192.

Haynes, J. R. 1992. Supposed pronounced ecophenotypy in foraminifera. Journal of Micropaleontology, 11: 59-63.

Hofker, J. 1930. Der Generationswechsel von Rotalia beccarii var. flevensis, nov. var. Zeitschrift für Zellforschung und mikroskopische Anatomie, 10: 757-768.

Hofker, J. 1951. The foraminifera of the Siboga expedition; part III. Siboga Expedition Monograph, Leiden, no.4b, pp. 498-502.

Hohenegger, J., Piller, W. E. \& Baal, C. 1993. Horizontal and vertical spatial microdistribution of foraminifers in the shallow subtidal Gulf of Trieste, Northern Adriatic Sea. Journal of Foraminiferal Research, 23: 79-101.

Holzmann, M. \& Pawlowski, J. 1996. Preservation of Foraminifera for DNA extraction and PCR amplification. Journal of Foraminiferal Research, 26: 264-267.

Holzmann, M. \& Pawlowski, J. 1997. Molecular, morphological and ecological evidence for species recognition in Ammonia (Foraminifera). Journal of Foraminiferal Research, 27: 311-318.

Holzmann, M., Piller, W. \& Pawlowski, J. 1996. Sequence variations in large-subunit ribosomal RNA gene of Ammonia (Foraminifera, Protozoa) and their evolutionary implications. Journal of Molecular Evolution, 43: 145-151.

Holzmann, M., Piller, W., Zaninetti, L., Fenner, R., Martini, R., Serandrei-Barbero, R. \& Pawlowski, J. 1998. Molecular versus morphologic variability in Ammonia spp. (Foraminifera, Protozoa) from the Lagoon of Venice, Italy. Revue de Micropaléontologie, 41: $59-69$.

Höttinger, L. 1980. Rotaliid Foraminifera: Schweizerische Paläontologische Abhandlungen, 101: 3-154.

Huber, T. B, Bijma, J. \& Darling, K. 1997. Cryptic speciation in the living planktonic foraminifer Globigerinella siphonifera (d'Orbigny). Paleobiology, 23: 33-62.

Janke, K. \& Kraemer, B. P. 1990. Düne, Strand und Wattenmeer. Tiere und Pflanzen unserer Küste, Frankh'sche Verlagshandlung, Stuttgart.

Jorissen, F. J. 1988. Benthic foraminifera from the Adriatic Sea; principles of phenotypic variation. Utrecht Micropaleontological Bulletins, 37: 7-139.

Kimura, M. 1980. A simple method for estimating evolutionary rates of base substitutions through comparative studies of nucleotide se- 
quences. Journal of Molecular Evolution, 16: 111-120.

Larsen, N. G. J, Maidak, B. L., McCaughey, M. J., Overbeek, R., Macke, T. J., Marsh, T. L. \& Woese, C. R. 1993. The ribosomal database project. Nucleic Acids Research, 21: 3021-3023.

Le Calvez, Y., 1977. Foraminiferès de l'lle de Cuba. Cahiers de Micropaléontologie, 2: 92-94.

Linné, C. 1758. Systemae naturae, edition 10, Stockholm, Sweden, tomus $1,710 \mathrm{p}$.

Matoba, Y. 1970. Distribution of recent shallow water Foraminifera of Matsushima Bay, Miyagi prefecture, northeast Japan. Scienctific Reports of the Tohoku University, 2nd serie (Geology), 42: 1-85.

Neefs, J. M. \& de Wachter, R. 1990. A proposal for the secondary structure of a variable area of eukaryotic small ribosomal subunit RNA involving the existence of a pseudoknot. Nucleic Acids Research, 18: $5695-5704$.

Olsen, G. J., Matsuda, H., Hagstrom R. \& Overbeek, R. 1994. Fast DNAml: a tool for construction of phylogenetic trees of DNA sequences using maximum likelihood. Computer Applications in the Biosciences, 10: 41-48.

Orbigny, A. d'. 1826. Tableau méthodique de la classe des Céphalopodes. 3 me ordre - Foraminifères. Annales du Museum d'Histoire Naturelles, Paris, tome 7, $275 \mathrm{p}$.

Orbigny, A. d'. 1839a. Foraminifères: In: Ramon de la Sagra, Histoire physique et naturelle de l'Ile de Cuba. A. Bertrand, Paris, France.

Orbigny, A. d'. 1839b. Voyage dans l'Amerique Méridionale; Foraminifères. Strasbourg, France, Levrault, 1839, tome 5, pt. 5, 45 p.

Pawlowski, J., Bolivar, I., Fahrni, J. \& Zaninetti, L. 1995. DNA analysis of 'Ammonia beccarii' morphotypes: one or more species?. Marine Micropaleontology, 26: 171-178.

Pawlowski, J., Bolivar, I., Fahrni, J., Cavalier-Smith, T. \& Gouy, M. 1996. Early origin of foraminifera suggested by SSU rRNA gene sequences. Journal of Molecular Biology and Evolution, 13: 445-450.

Perriere, G. \& Gouy, M. 1996. WWW-Query: an on-line retrieval system for biological sequence banks. Biochimie, 78: 364-369.

Phleger, F. B. 1970. Foraminiferal populations and marine marsh processes. Limnology and Oceanography, 15: 522-534.

Poag, C. W. 1978. Paired foraminiferal ecophenotypes in Gulf Coast estuaries: ecological and paleoecological implications. Transactions of the Gulf Coast Association of Geological Societies, 28: 395-421.

Reineck, H. E., (Ed.). 1978. Das Watt; Ablagerungs- und Lebensraum. Verlag W. Kramer, Frankfurt a. Main, 184 pp.

Richter, G. 1967. Faziesbereiche rezenter und subrezenter Wattsedimente nach ihren Foraminiferengemeinschaften. Senckenbergiana Lethaia, 48: 291-335.

Saitou, N. \& Nei, M. 1987. The neighbor-joining method: a new method for reconstructing phylogenetic trees. Molecular Biology and Evolution, 4: 406-425.

Schnitker, D. 1971. Distribution of Foraminifera on the North Carolina continental shelf. Tulane Studies in Geology and Paleontology, 8: 169215 .

Schnitker, D. 1974. Ecophenotypic variation in Ammonia beccarii (Linné). Journal of Foraminiferal Research, 4: 216-223.

Schultze, M. S. 1854. Ueber den Organismus der Polythalamien (Foraminiferen) nebst Bernerkungen ueber die Rhizopoden im allgemeinen. Leipzig, Deutschland, Engelmann, $54 \mathrm{pp}$.

Shupack, B. 1934. Some Foraminifera from western Long Island and New York Harbour. American Museum Novitates, 737: 1-12.

Vénec-Peyré, M. T. 1980. Microanalyseur ionique et microsonde moléculaire a laser mole: application à l'étude chimique et minéralogique du test d'Ammonia beccarii (Linné), foraminifère. Bulletin Centre Recherche Exploration - Production Elf - Aquitaine, 4: 55-79.

Vénec-Peyré, M. T. 1983. Etude de la croissance et de la variabilité chez un foraminifère benthique littoral Ammonia beccarii (Linné) en Méditerranée Occidentale. Cahiers de Micropaléontologie, 2: 5-32.

Walton, W. R. \& Sloan, B. J. 1990. The genus Ammonia Brünnich, 1772 its geographic distribution and morphologic variability. Journal of Foraminiferal Research, 20: 128-156.

Wang, P. \& Lutze, G. F. 1986. Inflated later chambers: ontogenetic changes of some recent hyaline benthic foraminifera. Journal of Foraminiferal Research, 16: 48-62.

Zaninetti, L. 1984. Les Foraminifères du salin de Bras del Port (Santa Pola, Espagne), avec remarques sur la distribution des Ostracodes. Revista D'Investigacions Geologiques, Barcelona, 38/39: 123-138. 